\title{
HUBUNGAN KESEIMBANGAN DAN KEMANDIRIAN DALAM MELAKUKAN ACTIVITY DAILY LIVING (ADL) TERHADAP FUNGSI KOGNITIF LANSIA DI PWRI KOTA DENPASAR
}

\author{
*Ida Ayu Astiti Suadnyana ${ }^{1}$, KomangTri Adi Suparwati ${ }^{2}$ I Gusti Agung Haryawan ${ }^{3}$ \\ Program Studi Fisioterapi Fakultas Ilmu-Ilmu Kesehatan Universitas Bali Internasional ${ }^{1,2}$ \\ Program Studi Kesehatan Dan Keselamatan Kerja Fakultas Ilmu-Ilmu Kesehatan Universitas Bali \\ Internasional $^{3}$ \\ astiti.utek@gmail.com¹, komangtriadisuparwati@gmail.com²
}

\begin{abstract}
The problems that occur in the elderly are generally caused by degenerative processes where in the elderly. Decreasing of cognitive function would leads to decreased perception, sensory, motor response and decreased propioseptif receptors in the central nervous system (CNS). Decreased of cognitive function also affected on balance and independence of activity daily living. This study aims to determine the relationship between balance and independence of activity daily living on cognitive function in the elderly. This research is a cross-sectional study. The population in this research is the elderly at PWRI Denpasar City. This study was using a simple random method, which 45 respondents fullfilled the inclusion and exclusion criteria. The measurement of cognitive function completed by mini mental state examination, independence of activity daily living completed by index katz and balance test measured by times up and go test. Data were analyzed with computer software, using the chi square test. The results between balance and cognitive function with chi-square test, showed $p=0.000(p<0.05)$ and the the results between independence of activity daily living and cognitive function in the elderly at PWRI Denpasar City, showed $p=0.000$ ( $p<0.05$ ). It can be concluded that there is a significant relationship between balance and cognitive function. There is also significant relationship between independence of activity daily living and cognitive function in the elderly at PWRI Denpasar City.
\end{abstract}

Keywords : Cognitive Function, Balance, Independence Of Activity Daily Living, Elderly.

\begin{abstract}
ABSTRAK
Permasalahan yang terjadi pada lansia pada umumnya disebabkan oleh proses degeneratif dimana pada lansia terjadi penurunan fungsi kognitif yang menyebabkan penurunan persepsi, sensori, respon motorik dan penurunan reseptor propioseptif pada sistem saraf pusat (SSP). Penurunan fungsi kognitif ini juga berdampak pada keseimbangan dan juga kemandirian lansia dalam melakukan aktivitas sehari-hari. Penelitian ini bertujuan untuk mengetahui hubungan keseimbangan dan kemandirian dalam melakukan activity daily living terhadap fungsi kognitif lansia. Penelitian ini menggunakan rancangan crosssectional study. Populasi pada penelitian ini adalah lansia di PWRI Kota Denpasar. Penelitian ini menggunakan metode acak sederhana dimana didapatkan responden sebanyak 45 orang yang telah memenuhi kriteria inklusi dan eksklusi. Pengukuran fungsi kognitif dilakukan dengan menggunakan MMSE, tes keseimbangan diukur menggunakan times up and go test dan pengukuran kemandirian activity daily living (ADL) diukur menggunakan index katz. Data dianalisis dengan software komputer yaitu dengan uji chi square untuk mengetahui hubungan keseimbangan dan kemandirian dalam melakukan activity daily living terhadap fungsi kognitif lansia. Hasil analisis hubungan antara keseimbangan terhadap fungsi kognitif lansia dengan uji chi-square, didapatkan hasil $\mathrm{p}=0,000(\mathrm{p}<0,05)$ dan hasil analisis hubungan antara kemadirian dalam melakukan activity daily living terhadap fungsi kognitif lansia dengan uji chi-square, didapatkan hasil $\mathrm{p}=0,000(\mathrm{p}<0,05)$. Terdapat hubungan yang bermakna antara keseimbangan terhadap fungsi kognitif lansia dan juga terdapat hubungan yang bermakna antara kemandirian dalam melakukan activity daily living (ADL) terhadap fungsi kognitif lansia di PWRI Kota Denpasar.
\end{abstract}

Kata Kunci $\quad$ : Fungsi Kognitif, Keseimbangan, Kemandirian Activity Daily Living Lansia. 


\section{PENDAHULUAN}

Perkembangan dan perubahan zaman di era globalisasi ini membawa bangsa Indonesia mengalami kemajuan di berbagai bidang. Perkembangan dan kemajuan di berbagai bidang khususnya bidang kesehatan dan teknologi menyebabkan meningkatnya usia harapan hidup (UHH) manusia. Peningkatan UHH tidak hanya dijadikan sebagai tolak ukur keberhasilan pembangunan saja, tetapi juga sebagai tantangan dalam proses pembangunan ke depannya. Jumlah lansia di Indonesia akan semakin bertambah, dimana pertambahan usia ini akan diikuti dengan bertambahnya berbagai permasalahan pada lansia.

Berdasarkan data Kementerian Kesehatan, usia harapan hidup di Indonesia pada tahun 2011 adalah 69,65 tahun dengan persentase populasi lansia yaitu 7,58\% selanjutnya pada tahun 2012 persentase ratarata populasi lansia di Indonesia mencapai 7,65\% dan Provinsi Bali telah melebihi persentase rata-rata populasi nasional tersebut hingga mencapai $9,78 \%$ yang berada di peringkat ke-4 dengan populasi lansia terbanyak di Indonesia (Kemenkes, 2013). Beberapa perubahan yang ditimbulkan oleh karena adanya proses degeneratif tersebut antara lain adanya perubahan pada sistem neuromuskular, muskuloskeletal, somatosensoris, vestibular dan juga sistem visual (Alfieri et al., 2012). Perubahan-perubahan ini nantinya akan bedampak pada penurunan kemampuan aktifitas fisik, keseimbangan hingga sampai pada penurunan fungsi kognitif.

Perubahan yang terjadi pada sistem neurologis di otak akan berpengaruh pada stabilitas tubuh seperti pada saraf motorik yang dapat mengakibatkan perubahan dalam refleks. Pada sistem sensori, lansia dapat mengalami gangguan visual, vestibular dan propriosepsi (Achmanagara, 2012). Perubahan yang terjadi pada sistem muskuloskeletal adalah berkurangnya kecepatan, fleksibilitas otot, penurunan kekuatan dan kontraksi otot. Penurunan fungsi tersebut akan mengakibatkan berkurangnya kemampuan untuk mempertahankan keseimbangan, sehingga resiko jatuh pada lansia akan meningkat (Nugraha, 2016).

Penelitian terkini juga menyebutkan terdapat perubahan struktur otak manusia seiring bertambahnya usia yang disebabkan oleh penyakit neurodegeneratif. Perubahan patologis pada serebrovaskular juga berhubungan dengan kemunduran fungsi kognitif. Hal tersebut tentunya juga akan berpengaruh pada aktivitas sehari-hari (activity daily living) sehingga dapat menurunkan kualitas hidup lansia yang berimplikasi pada kemandirian dalam melakukan aktivitas hidup sehari-hari (Nugroho, 2008). Perubahan fisik lansia akan mempengaruhi tingkat kemandirian.

Fungsi kognitif adalah suatu proses pengolahan masukan sensoris (taktil, visual dan auditorik) untuk diubah, diolah dan disimpan serta selanjutnya digunakan untuk menghubungkan interneuron secara sempurna sehingga suatu individu mampu melakukan penalaran terhadap masukan sensoris tersebut. Fungsi kognitif meliputi aspek-aspek tertentu yang dikenal dengan domain kognitif yaitu atensi, memori, bahasa, kemampuan visuospasial dan fungsi eksekutif (fungsi perencanaan, pengorganisasian dan pelaksanaan) (Wreksoatmaja, 2010).

Gangguan fungsi kognitif merupakan masalah yang serius hal ini dikarenakan dapat mengganggu kemandirian dalam melakukan aktivitas sehari-hari lansia di masa yang akan datang. Kondisi gangguan fungsi kognitif ini sangat bervariasi dari ringan, sedang hingga berat. Pada lansia penurunan fungsi kognitif dapat terjadi secara fisiologis atau secara patologis akibat penyakit di otak. Pada penurunan fungsi kognitif dapat terjadi penurunan kemampuan untuk mempertahankan keseimbangan akibat terjadinya perubahan 
pada sistem sensorik, motorik dan sistem saraf pusat (Shigemori, 2010).

Tingkat kognitif juga dapat mempengaruhi kemampuan seseorang dalam melakukan aktivitas sehari-hari. Lansia yang mempunyai fungsi kognitif tinggi maka dalam melaksanakan aktivitas sehari-hari dapat dilakukan secara mandiri, sehingga semakin tinggi fungsi kognitif maka semakin tinggi pula tingkat kemandirian lansia dalam melaksanakan aktivitas sehari-hari atau activity daily living. Fungsi kognitif merupakan salah satu faktor yang dapat mempengaruhi tingkat kemandirian dalam menjalani aktivitas sehari-hari selain faktor kesehatan fisiologis, umur, fungsi psikososial dan tingkat stress (Shigemori, 2010). Berdasarkan hal tersebut maka peneliti akan melakukan penelitian yang bertujuan untuk mengetahui lebih dalam hubungan keseimbangan dan kemandirian dalam melakukan activity daily living (ADL) terhadap fungsi kognitif lansia di PWRI Kota Denpasar.

\section{METODE}

Penelitian ini merupakan penelitian observasional analitik dengan rancangan belah lintang (cross sectional). Dimana pada penelitian ini pendataan tingkat kognitif, keseimbangan dan activity daily living dilakukan pada saat yang sama, artinya setiap subjek penelitian diambil datanya satu kali dengan menggunakan tes mini mental state examination (MMSE), times up and go test (TUGT) dan index katz. Pendataan fungsi kognitif, keseimbangan dan kemandirian activity daily living selanjutnya ditelusuri apakah ada hubungan keseimbangan dan kemandirian dalam melakukan activity daily living (ADL) terhadap fungsi kognitif lansia di PWRI Kota Denpasar.

Penelitian dilakukan di PWRI Kota Denpasar pada bulan Agustus 2020, yang dilakukan dalam kurun waktu dua hari. Populasi dalam penelitian ini adalah seluruh lansia di PWRI Kota Denpasar yang memenuhi kriteria inklusi dan eksklusi. Sampel pada penelitian ini adalah seluruh lansia yang berada di PWRI Kota Denpasar. Teknik pengambilan sampel dalam penelitian ini adalah teknik acak sederhana. Berdasarkan rumus acak sederhana diperoleh besaran sampel dalam penelitian yang dilakukan di PWRI Kota Denpasar dengan jumlah total populasi lansia sebesar 45 orang lansia.

\section{HASIL}

\section{Karakteristik Responden}

Dalam penelitian ini yang menjadi responden adalah lansia di PWRI Kota Denpasar dengan teknik pengambilan sampel menggunakan teknik acak sederhana yang telah memenuhi kriteria inklusi dan eksklusi. Sesuai dengan rumus besar sampel yang digunakan maka responden dalam penelitian ini berjumlah 45 orang. Adapun karakteristik responden berdasarkan umur, jenis kelamin, keseimbangan dan kemandirian dalam melakukan aktivitas sehari-hari yang berhubungan dengan fungsi kognitif dapat dilihat pada tabel berikut ini :

\section{Karakteristik Responden}

Tabel 1. Karakteristik Responden Berdasarkan Usia

\begin{tabular}{cccc}
\hline $\begin{array}{c}\text { Kelompo } \\
k\end{array}$ & $\begin{array}{c}\text { Usia } \\
\text { Min. }\end{array}$ & $\begin{array}{c}\text { Usia } \\
\text { Maks. }\end{array}$ & $\begin{array}{c}\text { Rata- } \\
\text { rata } \pm \text { SD }\end{array}$ \\
\hline $60-80$ & 60 & 80 & $65,78 \pm$ \\
& & & 5,317 \\
\hline
\end{tabular}

Responden dengan usia minimum yaitu 60 tahun, usia maksimum 80 tahun, dengan nilai rata-rata 65,78 dan standar deviasi sebesar 5,317 dimana total keseluruhan responden berjumlah 45 orang lansia.

Tabel 2. Karakteristik Responden Berdasarkan Jenis Kelamin

\begin{tabular}{ccc}
\hline $\begin{array}{c}\text { Jenis } \\
\text { Kelamin }\end{array}$ & Frekuensi (f) & $\begin{array}{c}\text { Persentase } \\
(\%)\end{array}$ \\
\hline Laki-Laki & 19 & $42,2 \%$ \\
Perempuan & 26 & $57,8 \%$ \\
\hline Jumlah & 45 & $100 \%$ \\
\hline
\end{tabular}


Responden berjenis kelamin perempuan lebih banyak yaitu berjumlah 26 responden $(57,8 \%)$ dari pada responden berjenis kelamin laki-laki dengan jumlah 19 responden $(42,2 \%)$.

Tabel 3. Karakteristik Responden Berdasarkan Fungsi Kognitif

\begin{tabular}{ccc}
\hline $\begin{array}{c}\text { Fungsi } \\
\text { Kognitif }\end{array}$ & Frekuensi (f) & $\begin{array}{c}\text { Persentase } \\
(\%)\end{array}$ \\
\hline Normal & 40 & $88,9 \%$ \\
$\begin{array}{c}\text { Gangguan } \\
\text { ringan }\end{array}$ & 5 & $11,1 \%$ \\
\hline Jumlah & 45 & $100 \%$ \\
\hline
\end{tabular}

Terdapat responden dengan fungsi kognitif normal berjumlah 40 orang $(88,9 \%)$ dan responden yang mengalami gangguan fungsi kognitif ringan berjumlah 5 orang $(11,1 \%)$.

Tabel 4. Distribusi Responden Berdasarkan Keseimbangan

\begin{tabular}{ccc}
\hline Keseimbangan & Frekuensi (f) & $\begin{array}{c}\text { Persentase } \\
(\%)\end{array}$ \\
\hline Baik & 29 & $64,4 \%$ \\
Resiko Jatuh & 15 & $33,3 \%$ \\
$\begin{array}{c}\text { Rendah } \\
\text { Resiko Jatuh } \\
\text { Tinggi }\end{array}$ & 1 & $2,3 \%$ \\
\hline Jumlah & 45 & $100 \%$ \\
\hline $\begin{array}{c}\text { Jumlah } \\
\text { keseimbangan }\end{array}$ & $\begin{array}{c}\text { responden } \\
\text { baik adalah }\end{array}$ & 29 dengan \\
orang
\end{tabular}

$(64,4 \%)$, responden dengan keseimbangan resiko jatuh rendah berjumlah 15 orang $(33,3 \%)$ dan responden dengan keseimbangan resiko tinggi berjumlah 1 orang $(2,3 \%)$.

Tabel 5. Distribusi Responden Berdasarkan Kemandirian dalam Activity Daily Living (ADL)

\begin{tabular}{ccc}
\hline $\begin{array}{c}\text { Kemandirian } \\
\text { ADL }\end{array}$ & Frekuensi (f) & $\begin{array}{c}\text { Persentase } \\
(\%)\end{array}$ \\
\hline $\begin{array}{c}\text { Normal } \\
\text { Ketergantungan } 1\end{array}$ & 43 & $95,6 \%$ \\
fungsi & 2 & $4,4 \%$ \\
\hline Jumlah & 45 & $100 \%$ \\
\hline Terdapat & responden & dengan
\end{tabular}

kemandirian ADL yang normal berjumlah 43 responden $(95,6 \%)$ dan kemandirian ADL dengan ketergantungan satu fungsi berjumlah 2 responden $(4,4 \%)$.

\section{Hubungan Antara Keseimbangan Terhadap Fungsi Kognitif Lansia}

Untuk mengetahui apakah ada hubungan antara keseimbangan dengan fungsi kognitif lansia di PWRI Kota Denpasar dilakukan uji chi-square. Tabel silang dan hasil uji chi-square dapat dilihat pada tabel berikut:

Tabel 6. Tabel Silang Keseimbangan terhadap Fungsi Kognitif Lansia

\begin{tabular}{|c|c|c|c|c|c|c|c|}
\hline \multirow{3}{*}{ Keseimbangan } & \multicolumn{4}{|c|}{ Fungsi Kognitif } & \multicolumn{2}{|c|}{ Total } & \multirow[t]{2}{*}{$\mathrm{P}$} \\
\hline & \multicolumn{2}{|c|}{ Baik } & \multicolumn{2}{|c|}{$\begin{array}{c}\text { Gangguan } \\
\text { Kognitif } \\
\text { Ringan }\end{array}$} & & & \\
\hline & $\mathrm{f}$ & $\%$ & $\mathrm{f}$ & $\%$ & $\mathrm{n}$ & $\%$ & \\
\hline Baik & 29 & 64,5 & 0 & 0 & 29 & 64,5 & \\
\hline $\begin{array}{l}\text { Resiko Jatuh } \\
\text { Rendah }\end{array}$ & 11 & 24,5 & 4 & 8,8 & 15 & 33,3 & 0,000 \\
\hline Resiko Jatuh Tinggi & 0 & 0 & 1 & 2,2 & 1 & 2,2 & \\
\hline Jumlah & 40 & 89 & 5 & 11 & 45 & 100 & \\
\hline
\end{tabular}

Responden dengan fungsi kognitif baik dengan keseimbangan baik berjumlah 29 responden $(64,5 \%)$, kemudian lansia dengan fungsi kognitif baik dengan resiko jatuh rendah sebanyak 11 orang $(24,5 \%)$. Selanjutnya lansia yang mengalami gangguan kognitif ringan dengan resiko jatuh resiko jatuh rendah sebanyak 4 responden $(8,8 \%)$ dan lansia yang mengalami gangguan fungsi kognitif ringan dengan resiko jatuh tinggi yaitu 1 responden $(2,2 \%)$.

Hasil penelitian menggunakan uji hipotesis Chi-square diperoleh nilai $p$ sebesar 0,000 maka dengan ini dapat disimpulkan $(\mathrm{p}<0,05)$ ini menunjukkan 
bahwa ada hubungan yang signifikan antara keseimbangan terhadap fungsi kognitif pada lansia di PWRI Kota Denpasar.

\section{Hubungan Antara Kemandirian ADL} Terhadap Fungsi Kognitif Lansia
Untuk mengetahui apakah ada hubungan antara kemandirian dalam melakukan ADL dengan fungsi kognitif lansia di PWRI Kota Denpasar dilakukan uji chi-square. Tabel silang dan hasil uji chi-square dapat dilihat pada tabel berikut:

Tabel 7. Tabel Silang Kemandirian ADL terhadap Fungsi Kognitif Lansia

\begin{tabular}{|c|c|c|c|c|c|c|c|}
\hline \multirow{4}{*}{$\begin{array}{c}\text { Kemandirian } \\
\text { ADL }\end{array}$} & \multicolumn{4}{|c|}{ Fungsi Kognitif } & \multirow{2}{*}{\multicolumn{2}{|c|}{ Total }} & \multirow{3}{*}{$\mathrm{P}$} \\
\hline & & & & & & & \\
\hline & \multicolumn{2}{|c|}{ Baik } & \multicolumn{2}{|c|}{$\begin{array}{c}\text { Gangguan Kognitif } \\
\text { Ringan }\end{array}$} & \multirow[b]{2}{*}{$\mathbf{n}$} & \multirow[b]{2}{*}{$\%$} & \\
\hline & $\mathbf{f}$ & $\%$ & $\mathbf{f}$ & $\%$ & & & \multirow{4}{*}{0,00} \\
\hline Normal & 40 & 88,9 & 3 & 6,7 & 43 & 95,6 & \\
\hline $\begin{array}{l}\text { Gangguan } 1 \\
\text { Fungsi }\end{array}$ & 0 & 0 & 2 & 4,4 & 2 & 4,4 & \\
\hline Jumlah & 40 & 88,9 & 5 & 11,1 & 45 & 100 & \\
\hline
\end{tabular}

Jumlah lansia yang memiliki fungsi kognitif baik dengan ADL yang normal berjumlah 40 responden $(88,9 \%)$, kemudian lansia dengan gangguan fungsi kognitif ringan dengan kemandirian dalam melakukan ADL normal berjumlah 3 responden $(6,7 \%)$ dan lansia yang mengalami ganggguan kognitif ringan dengan gangguan 1 fungsi yaitu berjumlah 2 responden $(4,4 \%)$.

Hasil penelitian setelah dilakukan uji chi-square test untuk mencari hubungan kemandirian dalam melakukan ADL terhadap fungsi kognitif pada lansia di PWRI Kota Denpasar diperoleh nilai $p$ sebesar 0,000. Dari analisis data dengan menggunakan metode uji chi-square test, maka didapatkan $(\mathrm{p}<0,05)$ ini menunjukkan bahwa ada hubungan yang bermakna antara kemandirian dalam melakukan ADL terhadap fungsi kognitif lansia pada lansia di PWRI Kota Denpasar.

\section{PEMBAHASAN}

\section{Karakteristik Responden}

Karakteristik berdasarkan usia dalam penelitian ini menunjukkan bahwa responden memiliki nilai rata-rata usia 65,7 tahun dengan standar deviasi sebesar 5,317 di mana total keseluruhan responden berjumlah 45 orang lansia, berdasarkan rumus besar sampel yang digunakan. Lansia yang aktif di organisasi PWRI Kota Denpasar didominasi oleh lansia`dengan rata-rata usia 65 tahun. Pada lansia akan terjadi proses degeneratif yang menyebabkan penurunan keseimbangan, penurunan kemampuan aktifitas sehari-hari dan juga adanya penurunan fungsi kognitif. Adanya penurunan fungsi kognitif dapat mengganggu aktivitas sehari-hari dan kemandirian lansia di masa yang akan datang.

Beberapa penelitian mengatakan bahwa usia berhubungan dengan gangguan keseimbangan, yang telah dibuktikan melalui penelitian longitudinal Stevens tahun 2011 yang menyatakan bahwa gangguan keseimbangan yang terjadi diakibatkan oleh penurunan fungsi muskuloskeletal yang terjadi seiring dengan bertambahnya usia. Usia juga mempengaruhi fungsi kognitif, dimana semakin meningkatnya usia maka menyebabkan terjadinya gangguan kognitif. Sebanyak 5\% dari lansia yang berumur 6570 tahun menderita demensia dan meningkat dua kali lipat setiap 5 tahun dan mencapai lebih dari $45 \%$ lansia pada umur di atas 85 tahun (Stevens, et al., 2011).

Karakterisitik responden berdasarkan jenis kelamin memperlihatkan bahwa responden berjenis kelamin wanita lebih banyak yaitu berjumlah 26 orang dan responden berjenis kelamin laki-laki yang 
berjumlah 19 orang. Pada penelitian ini responden wanita didapatkan lebih banyak yang menderita gangguan fungsi kognitif dari pada laki-laki, sebanyak 4 orang responden wanita dan 1 orang responden laki-laki yang mengalami gangguan kognitif ringan. Selain dikarenakan jumlah responden wanita yang lebih banyak persentase terjadinya gangguan fungsi kogntif ringan cenderung lebih besar pada wanita. Wanita memiliki faktor risiko terkena gangguan kognitif lebih banyak dari pada pria, hal ini disebabkan wanita memiliki fungsi fisik yang kurang baik dibandingkan dengan pria.

Menurut penelitian yang dilakukan oleh Myres menyatakan pendapatnya bahwa wanita lebih beresiko mengalami penurunan kognitif dari pada laki-laki. Hal ini disebabkan adanya peranan level hormon endogen dalam perubahan fungsi kognitif (Myres, 2008). Studi lain yang mengatakan bahwa prevalensi gangguan kognitif didapatkan pada pria, sedangkan laju penurunan fungsi kognitif lebih cepat terjadi pada wanita (Safitri, 2018). Penurunan fungsi kognitif pada lansia merupakan penyebab terbesar terjadinya ketidakmampuan dalam melakukan aktivitas normal sehari-hari, dan juga merupakan alasan tersering yang menyebabkan terjadinya ketergantungan terhadap orang lain untuk merawat diri sendiri (care dependence) pada lansia. Pengetahuan atau kognitif diperlukan untuk memenuhi kebutuhan lansia dan sikap juga dapat mempengaruhi perilaku lansia dalam kemandirian pemenuhan kebutuhan aktivitas sehari-hari (Zaskia, 2012).

Menurut WHO (dalam Rohmah, 2009) menyebutkan bahwa prevalensi gangguan kognitif meningkat sejalan bertambahnya usia, kurang dari 3\% terjadi pada kelompok usia 65-70 tahun dan lebih dari $25 \%$ terjadi pada kelompok usia 85 tahun ke atas. Berdasarkan penelitian yang dilakukan oleh Wreksoatmodjo di Jakarta, mendapatkan data lansia dengan fungsi kognitif buruk sebesar 37,8\% dari 286 responden (Wreksoatmodjo, 2015).

\section{Hubungan Antara Keseimbangan Terhadap Fungsi Kognitif Lansia}

Dalam penelitian ini yang menjadi responden adalah anggota lansia di PWRI Kota Denpasar. Pada distribusi responden berdasarkan fungsi kognitif didapatkan responden berjumlah 40 orang $(88,9 \%)$ dengan fungsi kognitif normal dan 5 orang $(11,1 \%)$ responden mengalami gangguan fungsi kognitif ringan. Fungsi kognitif otak diyakini mulai berkurang saat seorang memasuki usia 65 tahun. Penurunan fungsi kognitif terbesar terjadi pada responden wanita berusia 65-70 tahun, yaitu sebesar 9,5\% (Ramadian, 2013). Fungsi kognitif dapat dipengaruhi oleh beberapa faktor, termasuk gaya hidup, perilaku kesehatan, interaksi sosial, jenis pekerjaan dan perkembangan otak. Lansia di PWRI Kota Denpasar aktif dalam mengikuti berbagai kegiatan organisasi baik dari segi seni budaya dan olahraga, hal ini dapat mempengaruhi kinerja kognitif pada otak sehingga dapat menghambat terjadinya penurunan fungsi kognitif yang umumnya terjadi secara progresif.

Gangguan fungsi kogntif pada lansia dipengaruhi oleh proses degenerasi terutama pada efek penuaan lebih rentan terhadap aspek memori dan bahasa daripada domain kognitif yang karena pada lansia penurunan fungsi kognitif dapat terjadi secara fisiologis (sesuai usia) atau secara patologis akibat penyakit di otak. Pada lansia otak mengalami perubahan struktur dan fungsi otak terjadi di daerah prefrontal berdampak pada penurunan daya ingat jangka pendek, sulit berkonsentrasi. Selain itu densitas reseptor dopamine di otak juga menurun seiring bertambahnya usia, yang berperan dalam pengaturan perhatian dan modulasi respon terhadap rangsangan kontekstual dimana berpengaruh terhadap fungsi kognitif (Rahayu, 2014).

Berdasarkan distribusi keseimbangan didapatkan responden dengan 
keseimbangan baik berjumlah 29 responden $(64,4 \%)$ dan responden yang mengalami gangguan keseimbangan dengan resiko jatuh rendah berjumlah 15 responden $(33,3 \%)$ dan responden yang mengalami gangguan keseimbangan dengan resiko jatuh tinggi berjumlah 1 responden $(2,3 \%)$. Dari hasil penelitian ini dapat dilihat bahwa sebagian besar anggota lansia di PWRI memiliki keseimbangan yang cukup baik. Keseimbangan yang baik diperoleh dari berbagai faktor, salah satunya aktivitas fisik. Dengan melakukan aktivitas secara rutin maka akan menimbulkan gerakan fisik yang dapat menyebabkan terjadinya kontraksi otot. Aktivitas fisik dapat meningkatkan kebugaran jasmani, koordinasi, kekuatan otot yang berdampak pada perbaikan keseimbangan tubuh (Eni, 2018).

Hasil tabel silang fungsi kognitif dengan keseimbangan menunjukan lansia dengan fungsi kognitif baik dengan keseimbangan baik berjumlah 29 responden $(64,5 \%)$, kemudian lansia dengan fungsi kognitif baik dengan resiko jatuh rendah sebanyak 11 orang $(24,5 \%)$. Selanjutnya lansia yang mengalami gangguan kognitif ringan dengan resiko jatuh resiko jatuh rendah sebanyak 4 responden $(8,8 \%)$ dan lansia yang mengalami gangguan fungsi kognitif ringan dengan resiko jatuh tinggi yaitu 1 responden $(2,2 \%)$. Hasil uji chisquare yang dilakukan menunjukan hasil $p$ sebesar 0,000 dimana $(\mathrm{p}<0,05)$, yang membuktikan bahwa terdapat hubungan yang bermakna antara keseimbangan terhadap fungsi kognitif pada lansia.

Hasil penelitian telah membuktikan bahwa ada hubungan yang bermakna antara keseimbangan dan fungsi kognitif pada lansia. Hal ini dikarenakan fungsi kognitif memiliki peran sentral dalam regulasi keseimbangan pada orang lanjut usia. Hasil penelitian ini menunjukkan dimana lansia yang memiliki fungsi kognitif baik maka keseimbangannya juga baik selain itu lansia dengan fungsi kognitif baik memiliki resiko jatuh yang rendah. Hubungan antara fungsi kognitif dan keseimbangan dikarenakan adanya perubahan struktural atau fungsional dari otak berupa penyusutan volume hipokampus yang dikaitkan dengan keseimbangan dan kemampuan menjaga postur tubuh agar tetap tegak. Menurunnya volume kepadatan gray matter di gyrus frontal tengah dan gyrus frontal superior berdampak tidak hanya pada penurunan keseimbangan dalam kestabilan postural, namun juga pada penurunan kognitif (Makizako et al., 2014).

Pada lansia yang mengalami penurunan fungsi kognitif ditemukan beberapa gejala seperti mudah lupa yang berlanjut dengan kesulitan mengenal benda dan akhirnya tidak mampu menggunakan barang-barang sekalipun yang termudah sehingga lansia tersebut memiliki risiko terhadap cedera seperti terjatuh saat melakukan aktivitas fisik yang terbatas. Lansia yang mengalami gangguan kognitif awalnya ditemukan gejala mudah lupa berlanjut dengan kesulitan mengenal benda dan akhirnya tidak mampu menggunakan barang-barang sekalipun yang termudah (Robert et al., 2010).

Lansia dapat mengalami gangguan visuospasial, menyebabkan lansia mudah tersesat di lingkungannya dan dengan kondisi lansia yang mengalami kemunduran kapasitas fisiologis, misalnya kekuatan otot, kapasitas aerobik, koordinasi neuromotorik, dan fleksibilitas sehingga lansia tersebut memiliki risiko terhadap cidera seperti terjatuh saat melakukan aktivitas fisik yang terbatas (Eni, 2018). Selain itu dibutuhkannya atensi yang baik guna menjaga keseimbangan agar tidak jatuh dalam melakukan aktifitas. Salah satu aspek kognitif yaitu perhatian atau atensi, yang mempunyâ̂ peranan penting dalam keseimbangan pada lansia, dan atensi makin dibutuhkan pada keadaan-keadaan yang menyebabkan penurunan keseimbangan dan peningkatan risiko jatuh pada lansia (Handajani, 2016). 


\section{Hubungan Antara Kemandirian Dalam Activity Daily Living (ADL) Terhadap Fungsi Kognitif}

Melihat hubungan kemandirian dalam melakukan activity daily of living (ADL) terhadap fungsi kognitif, dimana dalam penelitian ini didapatkan nilai p 0,000 yang artinya terdapat hubungan yang bermakna antara kemandirian dalam melakukan ADL terhadap fungsi kognitif lansia di PWRI Kota Denpasar. Kemandirian dalam melakukan activity daily living ( $A D L)$ yang tinggi termasuk mandi, makan, berpakaian, berpindah, BAB, BAK dll. Teori diungkapkan oleh Weuve tahun 2004, dalam Nur Nafidah (2014) aktivitas fisik dan aktifitas sehari-hari dapat mempertahankan kesehatan vaskular otak dengan menurunkan tekanan darah, meninprofil meningkatkan lipoprotein mendukung produksi endotel nitrat oksidasi dan memastikan perfusi otak cukup, sehingga dapat mencegah atau menunda penurunan fungsi kognitif (Nafidah, 2014).

Pada dasarnya, fungsi kognitif akan mengalami penurunan secara normal seiring dengan penambahan usia. Selain itu, ada faktor risiko yang dapat mempengaruhi penurunan fungsi kognitif yaitu keturunan dari keluarga, tingkat pendidikan, cedera otak, tidak melakukan aktivitas fisik, dan penyakit kronik seperti parkinson, jantung, stroke serta diabetes, obesitas, nutrisi, intoksikasi obat (The U.S Departement of Health and Human Services, 2011). Akibat adanya penurunan fungsi kognitif dapat menimbulkan masalah yang cukup serius pada lansia karena dapat mengganggu aktivitas hidup sehari-hari dan kemandirian lansia di masa yang akan datang. Kondisi gangguan fungsi kognitif ini sangat bervariasi antara ringan, sedang dan berat.

Menurut Hardywinoto (2007) dalam penelitian trihayati (2017) menyatakan bahwa tingkat kognitif dapat mempengaruhi kemampuan seseorang dalam melakukan aktivitas sehari-hari. Fungsi kognitif menunjukan proses menerima, mengorganisasikan dan menginterpretasikan sensor stimulus untuk berpikir dan menyelesaikan masalah. Proses mental memberikan kontribusi pada fungsi kognitif dapat mengganggu dalam berpikir logis dan menghambat kemandirian dalam melaksanakan aktivitas sehari-hari. Penurunan fungsi kognitif ini dapat mengakibatkan para lansia sering bergantung pada orang lain untuk merawat diri sendiri (Trihayati, 2017).

Penurunan kemampuan dalam melaksanakan aktivitas sehari-hari pada lansia berdampak pada sifat ketergantungan pada orang lain. Ketergantungan lanjut usia terjadi penurunan aktivitas yang dapat menyebabkan peningkatan mordibitas dan mortalitas dan berdampak menurunnya kualitas hidup lansia (Maas, 2011). Nugroho 2008 dalam penelitian Nandini, 2015 mengungkapkan suatu teori dimana lansia yang mengalami kesulitan dalam melakukan pergerakkan fisik atau terdapat gangguan gerak, maka akan berpengaruh terhadap jumlah skor fungsi kognitifnya, dimana apabila terdapat gangguan gerak maka dapat menyebabkan penurunan fungsi kognitif yang lebih besar dibandingkan dengan yang tidak mengalami gangguan, penurunan fungsi kognitif berkaitan erat dengan penurunan kemandirian lansia (Nandini, 2015).

Hal ini sesuai dengan hasil yang didapat pada penelitian ini dimana $88,9 \%$ lansia di PWRI Kota Denpasar yang menjadi responden dengan fungsi kognitif baik maka tingkat kemandirian dalam melakukan ADLnya juga baik. Sehingga dapat disimpulkan bahwa semakin baik fungsi kognitifnya, semakin mandiri. Lansia yang mempunyai fungsi kognitif tinggi maka dalam melaksanakan aktivitas sehari-hari dapat dilakukan secara mandiri. Fungsi kognitif merupakan salah satu faktor yang dapat mempengaruhi tingkat kemandirian dalam menjalani aktivitas sehari-hari selain faktor kesehatan fisiologis, umur, fungsi psikososial dan tingkat stress. Semakin tinggi fungsi kognitif maka semakin tinggi 
pula tingkat kemandirian lansia dalam melaksanakan aktivitas sehari-hari.

\section{KESIMPULAN}

Berdasarkan hasil diatas dapat disimpulkan bahwa terdapat hubungan yang bermakna antara keseimbangan terhadap fungsi kognitif lansia di PWRI Kota Denpasar dimana fungsi kognitif yang baik maka maka akan menghasilkan keseimbangan yang baik guna mencegah terjadinya resiko jatuh dan juga terdapat hubungan yang bermakna antara kemandirian dalam melakukan ADL terhadap fungsi kognitif pada lansia di PWRI Kota Denpasar, dimana memang fungsi kognitif merupakan salah satu faktor yang dapat mempengaruhi tingkat kemandirian dalam melakukan ADL pada lansia, jika fungsi kognitif baik maka tingkat kemandirian dalam melakukan ADLnya juga baik.

\section{UCAPAN TERIMAKASIH}

Ucapan terimakasih disampaikan kepada PWRI Kota Denpasar yang telah membantu dalam proses penelitian serta semua pihak yang telah memberikan banyak bantuan dalam menyelesaikan penelitian ini.

\section{DAFTAR PUSTAKA}

Achmanagara, A.A. (2012). Hubungan Faktor Internal dan Eksternal dengan Keseimbangan Lansia di Desa Pamijen Sokaraja Banyumas. Tesis. Jakarta: Universitas Indonesia Library The Crystal of Knowledge Universitas Indonesia.

Alfieri FM, Riberto M, Abril-Carreres A, Boldó-Alcaine M, Rusca-Castellet E, Garreta-Figuera R, \& Battistella L. (2012). Effectiveness of an exercise program on postural control in frail older adults. Clin Interv Aging, 7:5938.

Eni, E., Aisyah, S. (2018). Gangguan Kognitif terhadap Resiko Jatuh Pada Lansia. Jurnal Ilmiah Ilmu Keperawatan Indonesia, 8(1), 363-369.
Fadhia, N., Ulfiana, E., \& Ismon, S. R. (2019). Hubungan Fungsi Kognitif Dengan Kemandirian Dalam Melakukan Activities Of Daily Living (Adl) Pada Lansia Di Upt Pslu Pasuruan. Indonesian Journal of Community Health Nursing, 1(1).

Guccione, 2012. Geriatric Physical Therapy. 3rd ed. Missouri: Elsevier Mosby.

Handajani, Y.S. (2016). Keseimbangan Postural Terhadap Aktivitas Kehidupan Sehari-Hari Pada Lansia. Jurnal Ilmiah Ilmu Keperawatan Indonesia, 5(1), 163-269.

Kemenkes, RI. (2013). Gambaran Kesehatan Lanjut Usia di Indonesia. Jakarta: Buletin Jendela Data dan Informasi Kesehatan.

Makizako, H., Shimada, H., Doi, T., Park, H., Tsutsumimoto, K., Suzuki, T. (2014). Moderate-intensity physical activity, cognition and apoe genotype in older adults with mild cognitive impairment. Science Medical Central, $1(1), 1-5$.

Maas, M.L. (2011). Asuhan Keperawatan Geriatrik. EGC : Jakarta

Myers, S. (2008). Claudication Distance and The Walking Impairment Qustionnaire best Describe The Ambulatory Limitations In Patients with Symtomatic Pheripheral Arterial Disease. Journal of Vascular Surgery, 47(3): 550-555.

Nandini, P.S. (2015). Hubungan Aktivitas Sosial, Interaksi Sosial, dan Fungsi Keluarga dengan Kualitas Hidup Lanjut Usia Di Wilayah Kerja Puskesmas I Denpasar Utara Kota Denpasar. Tesis. Denpasar: Universitas Udayana.

Nugraha, M.H.S., Wahyuni, N., Muliarta, I.M. (2016). Pelatihan 12 Balance Exercise Lebih Meningkatkan Keseimbangan Dinamis Daripada Balance Strategy Pada Lansia Di Banjar Bumi Santi, Desa Dauh Puri Kelod, Kecamatan Denpasar Barat. Majalah Ilmiah Fisioterapi Indonesia, 1(1).

Nugroho, W. (2008). Keperawatan Gerontik dan Geriatrik. 3rd ed. Jakarta: EGC.

Nafidah Nur. (2014). Hubungan Antara Aktivitas Fisik Dengan Tingkat Kognitif Lanjut Usia Di Panti Sosial 
Tresna Werdha Budi Mulia 4 Margaguna Jakarta Selatan. Skripsi. Program Studi Ilmu Keperawatan UIN Syarif Hidayatullah Jakarta.

Rahayu, P. (2014). Hubungan Fungsi Kognitif Dengan Risiko Jatuh Pada Lanjut Usia Di PSTW Unit Budhi Luhur Yogyakarta. Sekolah Tinggi Ilmu Kesehatan Aisyiyah.

Rohmah, A.S.N. (2009). Hubungan Antara Gangguan Gerak dan Fungsi Kognitif pada Wanita Lanjut Usia di Panti Werdha Surakarta. Universitas Muhammadiyah Surakarta.

Robert S, Carlos F, Mendes DL, Denis AE and Xinqi D. (2010). Self neglect and cognitive funtion among communitydwelling older persons. Int J Geriatri Psychiatry, 25: 798-806.

Ramadian D. (2013). Gambaran Fungsi Kognitif pada Lansia di Tiga Yayasan Manula di Kecamatan Kawangkoan. Jurnal e-CliniC, 1(1).

Safitri, Desnita, Coresa T. (2018). Gambaran Fungsi Kognitif Pada Lansia Di Unit Rehabilitasi Sosial Pucang Gading Semarang. J Kedokt Diponegoro, 3(1), 230-236.

Shigemori, K., Ohgi, S., Okuyama, E., Shimura, T., \& Schneider, E. (2010). The
Factorial Structure of The Mini Mental State Examination (Mmse) In Japanese Dementia Patients. Bmc Geriatrics, 10(1), 36.

Stevens FL, Hurley RA, Taber KH. (2011). Anterior Cingulate Cortex: Unique Role in Cognition and Emotion. $J$ Neuropsychiatry Clin Neurosci, 23(2) 121-5.

The U.S Departement of Health and Human Services. (2011). Physical activity and health older adults. Washington DC: Pennsylvania Avenue.

Trihayati, N. (2017). Hubungan Fungsi Kognitif Dengan Tingkat Kemandirian Aktivitas Sehari-Hari Pada Lansia Di Upt Panti Wredha Budhi Dharma Ponggalan Yogyakarta. Skripsi. Yogyakarta: Universitas Aisyiyah Yogyakarta.

Wreksoatmaja, B. R. (2015). Aktivitas kognitif memengaruhi fungsi kognitif lanjut usia di Jakarta. CDK, 42(1), 7-13.

Zaskia, Y. (2012). Faktor - Faktor yang Mempengaruhi Perilaku Lansia dalam Kemandirian Pemenuhan Kebutuhan ADL di Panti Sosial Tresna Werdha Budi Mulia 4 Margaguna Jakarta Selatan. Skripsi. Jakarta : Universitas Esa Unggul. 